\title{
Artur Kuś
}

\section{Rodzaje kompetencji Unii Europejskiej a unijna polityka podatkowa}

\section{Streszczenie}

W Unii Europejskiej aktualnie funkcjonują trzy rodzaje kompetencji: wyłączne, dzielone oraz wspierające (uzupełniające i harmonizujące). Dla każdego państwa bardzo ważne jest autonomiczne władztwo podatkowe i związana z tym samodzielność w kształtowaniu polityki podatkowej. Państwa przystępujące do Unii Europejskiej musiały się jednak liczyć z tym, że od momentu przystąpienia nie będą miały swoistego monopolu na tworzenie w pełni niezależnych i autonomicznych regulacji podatkowych. Prawo podatkowe UE służy przede wszystkim prawidłowemu funkcjonowaniu rynku wewnętrznego UE. Celem krajowego prawa podatkowego jest w głównej mierze zapewnienie dochodów państwu. Zatem główną cechą krajowego prawa podatkowego jest funkcja fiskalna, a unijnego - prawidłowe funkcjonowanie rynku wewnętrznego. Prawo podatkowe UE sensu largo stanowi zbiór przepisów prawa unijnego (pierwotnego i wtórnego) dotyczących i mających wpływ na prawo podatkowe poszczególnych państw członkowskich. Prawo podatkowe UE sensu stricto stanowi natomiast zbiór przepisów prawa unijnego odnoszących się i stosowanych bezpośrednio w prawie podatkowym państw członkowskich UE. W dużym uproszczeniu można przyjąć, że są to przepisy dotyczące opodatkowania przede wszystkim podatkami pośrednimi.

Słowa kluczowe: kompetencje Unii Europejskiej, unijne prawo podatkowe, suwerenność, podatki

\section{Types of competence of the European Union and EU tax policy}

\begin{abstract}
The European Union currently operates three types of competence: exclusive, shared and supporting (complementary and harmonization). For each country, it is very important autonomous power of taxation and the ensuing independence in shaping tax policy. Countries acceding to the European Union, however, have to reckon with the fact that
\end{abstract}


since joining will not have a kind of monopoly on the creation of a fully independent and autonomous tax regulations. EU tax law is primarily the proper functioning of the EU internal market. The aim of the tax legislation is mainly provide income for the state. Thus, the main feature of the national tax law is fiscal function and the EU's - the proper functioning of the internal market. EU tax law in the broad sense (sensu largo) is the collection of EU law (primary and secondary) concerning and affecting the tax law of the Member States. EU tax law in the strict sense (sensu stricto) is a set of rules while EU law relating to and used directly in the tax law of the Member States of the EU. In the simplest terms it can be assumed that these are the rules relating to the taxation mainly indirect taxes.

Keywords: competences of the European Union, EU tax law, sovereignty, taxes

Przystąpienie poszczególnych państw do Unii Europejskiej nie oznaczało wyzbycia się przez nie pełnej suwerenności na rzecz podmiotu prawa międzynarodowego, jakim jest obecnie Unia Europejska. Konsekwencją przystąpienia każdego z państw do Unii Europejskiej było przyjęcie acquis communautaire. Wiązało się to z koniecznością harmonizacji porządków prawnych oraz zaakceptowania wspólnych wartości i kanonów, w tym również europejskich standardów w zakresie podatków. Zgodzić się można z tym, że wartości znajdujące wyraz w Konstytucji RP ${ }^{1}$, jak i w traktatach unijnych ${ }^{2}$ (znowelizowanych traktatem lizbońskim) - wyznaczają tożsamość aksjologiczną Polski i Unii Europejskiej.

W sensie prawnym Unia Europejska nie jest ani państwem, ani federacją państw. Jednak osiągnięty stopień współpracy i współzależności gospodarczej oraz stopniowe wprowadzanie elementów typowych dla suwerennych państw (np. obywatelstwo, wspólna waluta euro w niektórych państwach członkowskich, znoszenie kontroli na granicach wewnętrznych - strefa Schengen) przyczynia się do wzrostu tożsamości europejskiej. Aktualnie suwerenność nie jest już jednak postrzegana jako nieograniczona możliwość wpływu na inne państwa lub jako wyraz potęgi niepodlegającej wpływom zewnętrznym. Tradycyjnie „suwerenność” definiowana jest bowiem jako „samowładność, czyli prawna niezależność od jakichkolwiek czynników zewnętrznych i całowładność, czyli kompetencja normowania wszystkich stosunków wewnątrz

1 Konstytucja Rzeczypospolitej Polskiej z dnia 2 kwietnia 1997 r., Dz. U. z 1997 r., nr 78, poz. 483 ze $\mathrm{zm}$.

2 Traktat z Lizbony zmieniający Traktat o Unii Europejskiej i Traktat ustanawiający Wspólnotę Europejską podpisany w Lizbonie dnia 13 grudnia 2007 r., OJ C 306, 17.12.2007, s. 1-271. 
państwa"3. Pojęcie absolutnej, niczym nieograniczonej suwerenności należy już jednak do przeszłości. Odróżnić można ograniczenia suwerenności, wynikające z woli państwa (tj. zgodne z prawem międzynarodowym), od naruszeń suwerenności następujących wbrew woli państwa i niezgodnych z prawem międzynarodowym (np. działania Rosji na Krymie). Takie świadome „ograniczenie suwerenności” wynikające z woli państwa ma miejsce właśnie w relacjach Rzeczpospolita Polska - Unia Europejska ${ }^{4}$

Kompetencje Unii Europejskiej w zakresie tworzenia regulacji prawnych w różnych dziedzinach prawa stanowią bardzo istotne zagadnienie, chociażby ze względu na pewnego rodzaju ograniczenia państw członkowskich w tym względzie. Niewątpliwie bardzo ważne dla każdego państwa jest autonomiczne władztwo podatkowe i związana z tym samodzielność w kształtowaniu polityki podatkowej. Państwa przystępujące do UE musiały się jednak liczyć z tym, że od momentu przystąpienia nie będą miały swoistego monopolu na tworzenie w pełni niezależnych i autonomicznych regulacji podatkowych. Niektóre kwestie podatkowe mające istotne znaczenie dla funkcjonowania rynku wewnętrznego (w domyśle - całej Unii Europejskiej) są bowiem regulowane już na poziomie unijnym. Pamiętać należy, iż państwa członkowskie UE mogą być związane regulacjami wynikającymi z międzynarodowego prawa podatkowego, a także poprzez umowy zawierane bezpośrednio przez UE z państwami trzecimi.

W związku z tym, po przystąpieniu poszczególnych państw do Unii Europejskiej, można wyróżnić kilka rodzajów obowiązujących i możliwych do zastosowania w praktyce norm podatkowych:

a) krajowe (wewnętrzne) prawo podatkowe,

b) unijne prawo podatkowe (prawo pierwotne, ogólne zasady prawa i zwyczaje, prawo pochodne - głównie dyrektywy i rozporządzenia),

c) międzynarodowe prawo podatkowe (w tym np. umowy o unikaniu podwójnego opodatkowania ${ }^{5}$, zwyczaje i orzecznictwo międzynarodowe),

d) międzynarodowe prawo podatkowe Unii Europejskiej (np. umowy zawierane przez UE z państwami trzecimi dotyczące opodatkowania).

Celem artykułu nie jest całościowa prezentacja zagadnień związanych z unijną polityką podatkową w kontekście kompetencji UE, lecz jedynie zasygnalizowanie podstawowych (wybranych) problemów definicyjnych i systemowych. Takie ujęcie

3 L. Ehrlich, Prawo międzynarodowe, Warszawa 1958, s. 123; szerzej na temat suwerenności zob. M. Dobrowolski, Zasada suwerenności narodu w warunkach integracji Polski z Unią Europejska, Lublin 2014, s. 76-83.

4 Por. A. Kuś, 10 lat Polski w Unii Europejskiej, „Przegląd Akademicki” 2014, nr 3, s. 37-38.

5 Szerzej zob. P. Selera, Prawo unijne a metody unikania podwójnego opodatkowania, „Europejski Przegląd Sądowy” 2010, nr 12, s. 16-20. 
problematyki może przyczynić się do dalszej dyskusji w kontekście coraz bardziej rozwijającego się unijnego prawa podatkowego.

\section{Rodzaje kompetencji Unii Europejskiej}

Pod pojęciem podziału kompetencji można rozumieć ich logiczne i celowe rozłożenie pomiędzy instytucje Unii Europejskiej a państwa członkowskie. Aktualnie (po regulacjach wynikających z traktatu lizbońskiego) de lege lata można wyodrębnić trzy rodzaje kompetencji Unii Europejskiej. Są to:

a) kompetencje wyłączne ${ }^{6}$,

b) kompetencje dzielone z państwami członkowskimi ${ }^{7}$,

c) kompetencje w zakresie wspierania, koordynowania lub uzupełniania działań państw członkowskich ${ }^{8}$.

Dokonując jednak bardziej ogólnego podziału, można również wskazać na kompetencje wyłączne i „inne” (dwie pozostałe tzw. niewyłączne). Podział ten nie jest expressis verbis wprowadzony w unijnych traktatach, ale jest również możliwy do przyjęcia. Zauważyć bowiem należy, iż zakres kompetencji wyłącznych wyznacza zakres kompetencji niewyłącznych. Są to bowiem wszystkie pozostałe. O ile kompetencje wyłączne stanowią w miarę jednolitą i jak się wydaje - zamkniętą grupę, to daje się zauważyć istotne zróżnicowanie i związane z tym „zamieszanie” pomiędzy kompetencjami niewyłącznymi. Jednym z celów traktatu lizbońskiego miało być rozstrzygnięcie niejasności związanych ze wszystkimi rodzajami kompetencji Unii. Wydaje się jednak, że cel ten nie został do końca osiągnięty. Wręcz przeciwnie - niejasności w tym zakresie zostały nawet bardziej pogłębione, co nie świadczy najlepiej o poziomie legislacji unijnej'.

W unijnym prawie pierwotnym zostały określone zadania stojące przed Unią Europejską. W celu ich realizacji różne instytucje i inne podmioty Unii Europejskiej

6 Są to aktualnie następujące dziedziny: a) unia celna, b) ustanawianie reguł konkurencji niezbędnych do funkcjonowania rynku wewnętrznego, c) polityka pieniężna w odniesieniu do państw członkowskich, których walutą jest euro, d) zachowanie morskich zasobów biologicznych w ramach wspólnej polityki rybołówstwa, e) wspólna polityka handlowa.

7 Por. art. 4 Traktatu o funkcjonowaniu Unii Europejskiej, Dz. U. C. 326 z 26 października 2012 r., dalej jako TFUE. Unia i państwa członkowskie mogą stanowić prawo, ale państwa członkowskie tylko, gdy UE nie wykonała swojej kompetencji - np. w zakresie polityki energetycznej.

8 Por. art. 5 TFUE; są to kompetencje, w ramach których Unia Europejska nie zastępuje kompetencji państw członkowskich, ale je uzupełnia - np. w zakresie polityki edukacyjnej.

9 Por. A. Kuś, Kompetencje wyłaczne Unii Europejskiej w zakresie Wspólnej Polityki Handlowej i Unii Celnej, Wydawnictwo KUL, Lublin 2012, s. 64-67; P. Saganek, Nowe reguly dotyczące podziału kompetencji między Unię Europejska a państwa członkowskie w świetle Traktatu z Lizbony, „Przegląd Sejmowy” 2010, nr 4, s. 83-106. 
zostały wyposażone we właściwe im kompetencje. Dzięki temu wykonywanie postawionych zadań traktatowych staje się realne i może być realizowane w praktyce. Wszystko, co czynią poszczególne podmioty i instytucje unijne ma być w swoim założeniu podporządkowane celowi w postaci integracji państw członkowskich Unii Europejskiej oraz wspierania pokoju, wartości stanowiących podstawę Unii Europejskiej, a także dobrobytu narodów państw członkowskich ${ }^{10}$.

Nie ulega wątpliwości, że powstanie Unii Europejskiej stworzyło na arenie międzynarodowej niespotykaną i nową w skali światowej sytuację polityczno-gospodarczą. Zaczął bowiem funkcjonować nieznany wcześniej podmiot, charakteryzujący się tym, że ma własne instytucje, organy, agencje oraz autonomiczny system prawny. Wszystkie działania Unii Europejskiej i jej instytucji powinny zatem być podporządkowane osiągnięciu zawartych w prawie pierwotnym celów i pogłębianiu integracji państw członkowskich. Jednym z widocznych specyficznych wyróżników Unii Europejskiej jest jej własny system prawny. System ten stanowi bowiem porządek prawny odrębny i niezależny zarówno od systemów prawnych państw członkowskich, jak i od systemu klasycznego publicznego prawa międzynarodowego ${ }^{11}$. Można zatem przyjąć, że prawo Unii Europejskiej jest nowym, szczególnym systemem prawnym, który charakteryzuje się własnymi regułami i ma autonomiczną pozycję na tle innych systemów prawnych. Poprzez swoją niezależność wymusza określone zasady stosowania, tak aby zapewnić swoim przepisom pełną skuteczność i efektywność. W celu osiągnięcia takiego rezultatu Trybunał Sprawiedliwości Unii Europejskiej ${ }^{12}$ w bogatym orzecznictwie wypracował katalog zasad stosowania prawa unijnego. Powstawały one na przestrzeni wielu lat i podlegają ciągłej kreatywnej ewolucji a nawet - szczególnie dzięki inspirującemu orzecznictwu krajowych sądów konstytucyjnych - stopniowej modyfikacji. Podkreślić trzeba, że zasady te nie zostały zapisane wprost (expressis verbis) $\mathrm{w}$ traktatach stanowiących podstawy funkcjonowania Unii. Nie stanowią zatem prawa pierwotnego, ani nawet prawa wtórnego Unii. Zostały stworzone w drodze orzecznictwa Trybunału Sprawiedliwości Unii Europejskiej i stanowią ważną część porządku prawnego. Pośród wspomnianych zasad wyróżnić można: zasadę bezpośredniego stosowania prawa Unii (zwaną też zasadą bezpośredniego skutku),

10 Por art. 3 Traktatu o Unii Europejskiej, Dz. U. C. 326 z 26 października 2012 r.; dalej jako TUE.

11 W klasycznym już orzeczeniu z 5 marca 1963 r. w sprawie Van Gend en Loos 26/62 Trybunał stwierdził, że „(...) Wspólnota stanowi nowy porządek prawnomiędzynarodowy, na rzecz którego państwa członkowskie ograniczyły w określonym zakresie swoje suwerenne prawa. Podmiotami tego porządku prawnego są zarówno państwa członkowskie, jak i ich obywatele”.

12 Wcześniej, powszechnie w literaturze przedmiotu, używano skrótu ETS, określając nim Trybunał Sprawiedliwości. Wszystkie wyroki Trybunału Sprawiedliwości dostępne na stronie http://curia.europa. eu, oficjalnej stronie internetowej Trybunału Sprawiedliwości Unii Europejskiej. 
zasadę pośredniego skutku (pojmowaną również jako prounijna wykładnia prawa) oraz zasadę pierwszeństwa (prymatu) prawa Unii Europejskiej.

Przekazanie kompetencji na rzecz UE nie jest absolutne i nie oznacza swoistego „ubezwłasnowolnienia legislacyjnego" państw członkowskich. Polski Trybunał Konstytucyjny w wyroku w sprawie Traktatu z Lizbony ${ }^{13}$ przyjął, że w zgodzie z polską Konstytucją przekazanie kompetencji „w niektórych sprawach” podlega istotnym ograniczeniom. Ograniczenia te można sformułować jako trzy podstawowe zakazy:

a) zakaz przekazania ogółu (czyli wszystkich) kompetencji danego organu,

b) zakaz przekazania kompetencji w całości spraw w danej dziedzinie,

c) zakaz przekazania kompetencji co do istoty spraw określających gestię danego organu władzy państwowej.

\section{Zasada kompetencji przyznanych}

Unia Europejska jako wspólnota prawa została oparta na konstrukcji zasady kompetencji przyznanych, często określanych zamiennie jako kompetencje powierzone. Zasada ta delimituje zarówno działanie unijnych instytucji, jak i państw członkowskich. Zgodnie z zasadą kompetencji przyznanych, państwa poprzez zawarcie traktatów stanowiących podstawę prawną Unii rezygnują w pewnym zakresie z samodzielności i przekazują Unii Europejskiej kompetencje do osiągnięcia ich wspólnych celów, zobowiązując się tym samym do przestrzegania postanowień traktatowych oraz prawa tworzonego na ich podstawie przez te instytucje. Przekazanie kompetencji Unii Europejskiej na podstawie traktatów odbywa się zgodnie z wymaganiami konstytucyjnymi państw członkowskich ${ }^{14}$.

Unia Europejska, jak każda organizacja międzynarodowa ma tyle kompetencji, ile - na mocy traktatu ustanawiającego organizację - przyznały jej państwa

${ }^{13}$ Oceny konstytucyjności Traktatu z Lizbony dokonał polski Trybunał Konstytucyjny w wyroku z dnia 24 listopada 2010 r. (sygn. akt K 32/09). Wyrok ten stanowi kontynuację linii orzeczniczej polskiego Trybunału, który odnosił się wielokrotnie w uzasadnieniu do wcześniejszego orzecznictwa związanego z integracją Polski z Unią Europejską (w szczególności do wyroku dotyczącego Traktatu Akcesyjnego o sygn. akt K 18/04). Wyrok ten wpisuje się także w ogólną filozofię europejskich sądów konstytucyjnych dokonujących oceny Traktatu z Lizbony. Ocena konstytucyjności Traktatu z Lizbony znalazła wyraz w wyrokach sądów konstytucyjnych kilku państw europejskich: Czech (26 listopada 2008 r. i 3 listopada 2009), Łotwy (7 kwietnia 2009 r.), Niemiec (30 czerwca 2009 r.) i Węgier (12 lipca 2010 r.) oraz decyzji francuskiej Rady Konstytucyjnej (20 grudnia 2007 r.), a także w postanowieniu austriackiego Trybunału Konstytucyjnego (30 września 2008 r.); szerzej: Relacje między prawem konstytucyjnym a prawem wspólnotowym w orzecznictwie sąów konstytucyjnych państw UE, red. K. Zaradkiewicz, Warszawa 2010.

${ }_{14}$ Por. P. Justyńska, Między supremacją a pierwszeństwem prawa unijnego. Jedność w różnorodności, w: Konferencja. Unia Europejska: zjednoczeni w różnorodności, Warszawa 14-15 grudnia 2010, red. C. Mik, Warszawa 2012, s. 136. 
członkowskie $^{15}$. Działa więc w granicach kompetencji powierzonych jej traktatami i celów w nich wyznaczonych. W ten sposób władza Unii istnieje dzięki powierzeniu kompetencji, a jej zakres wyznaczają nie tylko uzyskane kompetencje, lecz także cele wyznaczone w traktatach ${ }^{16}$. Kompetencje unijne nie są zatem kompetencjami pierwotnymi, lecz pochodną woli państw. Unia Europejska nie ma kompetencji do określania swoich własnych uprawnień, sama nie decyduje o swoich kompetencjach. Przyjęcie wiążącego aktu prawnego wymaga istnienia normy przyznającej uprawnienie do jego wydania ${ }^{17}$. Unia Europejska działa w granicach kompetencji przyznanych w traktatach oraz w świetle celów w nich wyznaczonych. Przyjmowane akty prawa pochodnego muszą być więc wydawane dla realizacji konkretnych celów Unii Europejskiej. Traktaty powierzają kompetencje do stanowienia prawa wyraźnie wskazanym unijnym instytucjom.

W związku z tym, Unia Europejska jest odpowiedzialna za jakąś sprawę na tyle, na ile kompetencje w tym zakresie zostały na nią przeniesione (przekazane) przez państwa członkowskie ${ }^{18}$. Określając rodzaje kompetencji przynależnych Unii Europejskiej i państwom członkowskim należy wskazać, że z TUE można wyinterpretować zasadę domniemania kompetencji państw członkowskich ${ }^{19}$. To domniemanie ma szczególne znaczenie w dziedzinie podatków i innych danin publicznych.

\section{Kompetencje wyłączne}

Zgodnie z legalną definicją kompetencji wyłącznej: „(...) Jeżeli Traktaty przyznają Unii wyłączną kompetencję w określonej dziedzinie, jedynie Unia może stanowić prawo oraz przyjmować akty prawnie wiążące, natomiast Państwa Członkowskie mogą to czynić wyłącznie z upoważnienia Unii lub w celu wykonania aktów Unii”20.

Z postanowień traktatowych wynika, że Unia Europejska ma wyłączne kompetencje w pięciu dziedzinach ${ }^{21}$ : a) unia celna, b) ustanawianie reguł konkurencji niezbędnych do funkcjonowania rynku wewnętrznego, c) polityka pieniężna w odniesieniu do

15 Por. art. 5 TUE.

${ }_{16}$ C. Mik, Europejskie prawo wspólnotowe. Zagadnienia teorii i praktyki, Warszawa 2000, s. 271-274.

17 Za wyjątkiem tzw. klauzuli elastyczności - por. art. 353 TFUE.

${ }^{18}$ Por. art. 5 ust. 1 zdanie 1 oraz ust. 2 TUE; por. również art. 1 ust. 1, art. 3 ust. 6, art. 4 ust. 1, art. 48 ust. 6 podustęp 3 TUE; art. 2 ust. 1 oraz ust. 2, art. 4 ust. 1, art. 7, art. 19, art. 32, art. 130, art. 132 ust. 1, art. 207 ust. 6, art. 337 TFUE; deklaracja nr $18 \mathrm{w}$ sprawie rozgraniczenia kompetencji; deklaracja nr 24 w sprawie osobowości prawnej Unii Europejskiej.

${ }^{19}$ Por. art. 4 ust. 1 oraz 5 ust. 2 zd. 2 TUE.

${ }^{20}$ Por. art. 2 ust. 1 TFUE.

${ }^{21}$ Por. art. 3 TFUE oraz Deklaracja nr 18 dotycząca rozgraniczenia kompetencji. 
państw członkowskich, których walutą jest euro, d) zachowanie morskich zasobów biologicznych w ramach wspólnej polityki rybołówstwa, e) wspólna polityka handlowa.

Jest to katalog zamknięty dziedzin, w których Unia Europejska ma wyłączną zdolność do tworzenia prawa. Unia ma także wyłączną kompetencję do zawierania umów międzynarodowych, jeżeli ich zawarcie zostało przewidziane w akcie prawodawczym Unii lub jest niezbędne do umożliwienia Unii wykonywania jej wewnętrznych kompetencji albo w zakresie, w jakim ich zawarcie może wpływać na wspólne zasady czy zmieniać ich zakres.

Państwa członkowskie przyznając Unii Europejskiej kompetencje wyłączne, przekazały jej uprawnienie do stanowienia prawa i przyjmowania aktów prawnie wiążących w określonych dziedzinach. Państwa członkowskie mogą przyjmować akty prawne wyłącznie z upoważnienia Unii lub w celu wykonania jej aktów ${ }^{22}$.

Wyłączność kompetencji Unii Europejskiej charakteryzuje się dwoma elementami: funkcjonalnym i materialnym. Element funkcjonalny obejmuje obowiązek Unii do działania w wyniku uznania jej za jedyny podmiot odpowiedzialny za realizację pewnych zadań. Tylko zatem Unia Europejska, a ściślej - jej instytucje (stosując specjalne procedury prawodawcze), mogą być aktywne we wskazanych dziedzinach. Element materialny obejmuje - co do zasady - utratę przez poszczególne państwa członkowskie możliwości samodzielnego działania w dziedzinie objętej kompetencją wyłączną ${ }^{23}$. Oznacza to przejęcie przez Unię Europejską wyłącznego prawa do decydowania w zakresie pięciu wskazanych dziedzin. Państwa członkowskie mają wpływ na poszczególne decyzje w tym zakresie, ale tylko poprzez aktywną działalność swoich przedstawicieli w poszczególnych instytucjach Unii Europejskiej (np. Radzie, Parlamencie). W rzeczywistości jednak owa „wyłączność” jest pewnego rodzaju specyficzną fikcją prawną i można ją raczej traktować jako wskazanie na ważne, z punktu widzenia Unii Europejskiej, dziedziny, które powinny podlegać monopolizacji instytucji unijnych. Dokonując bowiem analizy unijnych kompetencji wyłącznych, można zauważyć ogromny i twórczy wpływ organizacji międzynarodowych oraz „przełożenie” unijnej polityki zagranicznej na tworzenie prawa w tych dziedzinach.

22 Art. 2 ust. 1 TFUE.

${ }_{23}$ P. Saganek, Artykuł 5, w: Traktat ustanawiający Wspólnotę Europejską. Komentarz, red. A. Wróbel, t. 1 (art. 1-60), Warszawa 2008, s. 208. 


\section{Kompetencje dzielone}

Unia Europejska ma kompetencje dzielone w dziedzinach, które nie stanowią kompetencji wyłącznej lub kompetencji wspierających, uzupełniających i koordynujących ${ }^{24}$. Z powyższego postanowienia (dokonując wykładni literalnej) wynikałaby zasada domniemania kompetencji dzielonych. Kompetencje dzielone funkcjonują zatem zawsze, gdy nie dotyczą obszaru kompetencji wyłącznych oraz gdy nie są wyraźnie wskazane jako pozostałe kompetencje wspierające, uzupełniające czy też koordynujące. Zatem obszary, w których Unia Europejska dzieli kompetencje z państwami członkowskimi stanowią dziedziny wskazane w traktatach, które nie należą do dziedzin objętych kompetencją wyłączną Unii Europejskiej oraz nie mieszczą się w pozostałych kompetencjach ${ }^{25}$. Podział taki nie jest jednak do końca precyzyjny i łatwy do rozpoznania. Szczególnie trudne jest wyraźne oddzielenie kompetencji dzielonych i kompetencji tzw. wspierających. Takie postanowienie traktatowe wcale nie ułatwia zrozumienia - i tak przecież skomplikowanych - regulacji unijnego prawa.

Traktat o funkcjonowaniu Unii Europejskiej wskazuje na najważniejsze dziedziny objęte kompetencjami dzielonymi. Są nimi: rynek wewnętrzny, polityka społeczna w odniesieniu do aspektów określonych w TFUE, spójność gospodarcza, społeczna i terytorialna, rolnictwo i rybołówstwo, $\mathrm{z}$ wyłączeniem zachowania morskich zasobów biologicznych, środowisko naturalne, ochrona konsumentów, transport, sieci transeuropejskie, energia, przestrzeń wolności, bezpieczeństwa i sprawiedliwości, wspólne problemy bezpieczeństwa w zakresie zdrowia publicznego w odniesieniu do aspektów określonych w TFUE ${ }^{26}$.

Wykonywanie kompetencji dzielonych polega na tym, że zarówno Unia Europejska, jak i państwa członkowskie mogą stanowić prawo i przyjmować akty prawnie wiążące w określonej dziedzinie. Jednakże działanie państwa członkowskiego może mieć charakter następczy w stosunku do aktywności Unii. Państwa członkowskie wykonują bowiem swoją kompetencję w zakresie, w jakim Unia nie wykonała swojej kompetencji lub w jakim postanowiła zaprzestać wykonywania swojej kompetencji ${ }^{27}$.

24 Art. 4 ust. 1 TFUE.

25 Por. art. 6 TFUE.

26 Por. art. 4 TFUE.

27 Por. art. 2 ust. 2 TFUE. 


\section{Kompetencje wspierające, uzupełniające i harmonizujące}

W niektórych dziedzinach - i na warunkach przewidzianych w traktatach - Unia ma kompetencje w zakresie wspierania, uzupełniania i harmonizowania działań państw członkowskich, nie zastępując jednak ich kompetencji w tych dziedzinach ${ }^{28}$. Wspieranie kompetencji może oznaczać wspomaganie, popieranie lub nawet pobudzanie przez Unię Europejską działań poszczególnych państw członkowskich w ściśle określonych dziedzinach. Wspieranie takie może mieć różny wymiar (legislacyjny, finansowy, doradczy itp.). Uzupełnianie kompetencji może oznaczać dodawanie lub modyfikowanie już wykonywanych kompetencji przez państwa członkowskie (lub Unię) w celu realizacji wspólnych zadań w określonej dziedzinie. Oznaczać to może „dwutorowe”, ale zsynchronizowane, tworzenie prawa w danym zakresie tematycznym. Harmonizacja traktatowych kompetencji może przejawiać się jako dostosowanie, adaptacja czy wreszcie dopasowanie regulacji prawnych unijnych i państw członkowskich.

Z postanowień traktatowych wynika, że do podstawowych dziedzin kompetencji wspierających, uzupełniających i harmonizujących należąa ${ }^{29}$ ochrona i poprawa zdrowia, przemysł, kultura, turystyka, edukacja, kształcenie zawodowe, młodzież i sport, ochrona ludności, współpraca administracyjna. Współpraca może występować na poziomie państw członkowskich, ale także dotyczyć współpracy organów i instytucji krajowych oraz jednostek.

\section{Prawo podatkowe Unii Europejskiej}

Władztwo podatkowe ma kluczowe znaczenie dla suwerenności państw członkowskich, które w tej dziedzinie przyznały Unii jedynie ograniczone uprawnienia. Na szczeblu unijnym polityka podatkowa ma służyć zapewnieniu sprawnego funkcjonowania rynku wewnętrznego. Dlatego też działania UE zmierzające do harmonizacji w tej dziedzinie w głównej mierze koncentrują się na podatkach pośrednich. Równolegle z tymi działaniami UE podejmuje coraz bardziej zdecydowaną walkę z uchylaniem się od opodatkowania i unikaniem go, ponieważ zjawiska te stanowią zagrożenie dla uczciwej konkurencji, a także przyczyniają się do powstawania poważnych niedoborów w dochodach podatkowych. Zadaniem Unii Europejskiej jest

28 Art. 2 ust. 5 TFUE.

29 Art. 6 TFUE. 
zbliżanie ustawodawstw państw członkowskich, w tym również przepisów podatkowych, w celu zapewnienia prawidłowego funkcjonowania rynku wewnętrznego Unii Europejskiej. Wspólny sektor ekonomiczno-gospodarczy ma na celu zniesienie pomiędzy państwami członkowskimi barier w swobodzie przepływu towarów, osób, usług i kapitału. Jednym z instrumentów zmierzających do wypełniania celów Unii Europejskiej jest zbliżanie ustawodawstw krajowych w istotnych dla funkcjonowania gospodarki dziedzinach. Taką dziedziną niewątpliwie jest prawo podatkowe. Należy również zauważyć, iż prawo UE nie reguluje systemu podatkowego w całości, tylko odnosi się do poszczególnych (punktowych) zagadnień objętych tą tematyką. Nie jest to zatem kompetencja wyłączna Unii Europejskiej ${ }^{30}$. W poszczególnych państwach członkowskich istnieją odrębne i niezależne od innych systemy podatkowe, które tylko w pewnym zakresie podlegają wspólnej harmonizacji. W związku z tym można uznać, że kwestie podatkowe mieszczą się w kompetencjach „niewyłącznych” UE. W zależności od rodzaju podatków można je przyporządkować do kompetencji dzielonych lub wspierających.

Budowa jednolitego ugrupowania integracyjnego wymaga koordynacji wielu sektorów polityki, w tym również polityki w zakresie harmonizacji podatków. Nie jest łatwe sformułowanie kompleksowej definicji prawa podatkowego Unii Europejskiej. Polityka podatkowa jest częścią polityki fiskalnej (budżetowej), która obejmuje ogół decyzji dotyczących zarówno wydatków z budżetu UE, jak i podatków. Prawo podatkowe Unii Europejskiej jest niewątpliwie swoistym i specyficznym „tworem prawnym”, odmiennym od krajowego prawa podatkowego, i nie można opisywać go w kategoriach identycznych, jak krajowe prawo podatkowe. Prawo podatkowe UE jest przede wszystkim zbiorem przepisów będących instrumentem realizacji celów przewidzianych w traktatach. Cele prawa podatkowego UE, jego treść i zakres pozostają w ścisłym związku z celami Unii Europejskiej ${ }^{31}$. Celem UE jest wspieranie pokoju, jej wartości i dobrobytu jej narodów ${ }^{32}$. W dążeniu do tego celu utworzono rynek wewnętrzny ${ }^{33}$ będący obszarem bez granic wewnętrznych, na którym realizowane są cztery tzw. swobody europejskie. Prawo podatkowe UE służy zatem przede wszystkim prawidłowemu funkcjonowaniu rynku wewnętrznego UE, a celem krajowego prawa podatkowego jest w głównej mierze zapewnienie dochodów państwu. Zatem główną cechą polskiego prawa podatkowego jest funkcja fiskalna ${ }^{34}$, a unijnego - prawidłowe

${ }^{30}$ Chyba że uznamy politykę podatkową jako element unii celnej, a należności celne jako szczególnego rodzaju podatki.

${ }_{31}$ I. Andrzejewska-Czernek, Wykładnia prawa podatkowego Unii Europejskiej, Warszawa 2013, s. 24.

32 Art. 3 TUE.

33 Art. 3, ust. 3 TUE.

${ }^{34}$ Oprócz innych funkcji - redystrybucyjnej, stymulacyjnej, finansowej, gospodarczej i społecznej. 
funkcjonowanie rynku wewnętrznego. Cele i funkcje krajowego i unijnego prawa podatkowego różnią się zatem diametralnie. Funkcja fiskalna nie jest bowiem tożsama z zapewnieniem (realizacją) rynku wewnętrznego Unii Europejskiej. Ma zdecydowanie węższy charakter i jest ukierunkowana na poszczególne państwa członkowskie, a nie na Unię Europejską pojmowaną jako odrębne ugrupowanie integracyjne.

W tym kontekście można przyjąć założenie, iż podstawowe cele unijnej polityki podatkowej obejmują:

a) harmonizację poziomu stawek podatkowych oraz likwidację różnic w systemach podatkowych w dziedzinie podatków pośrednich, które mogłyby mieć szkodliwy wpływ na konkurencję w ramach rynku wewnętrznego,

b) usunięcie luk umożliwiających uchylanie się od podatków oraz zapobieganie podwójnemu opodatkowaniu w dziedzinie podatków bezpośrednich,

c) zapobieganie szkodliwym skutkom wewnętrznej konkurencji podatkowej.

Trzeba w tym miejscu również wskazać, że w prawie podatkowym UE zachodzi zasadnicza różnica pomiędzy regulacjami dotyczącymi podatków pośrednich a tymi dotyczącymi podatków bezpośrednich. Przepisy dotyczące podatków pośrednich zostały bowiem w dużym stopniu zharmonizowane. Przepisy dotyczące podatków bezpośrednich pozostają natomiast ciągle domeną państw członkowskich UE, a ich harmonizacja nastąpiła jedynie w niewielkim stopniu.

Czy można zatem zdefiniować prawo podatkowe UE? Nie jest to łatwe, gdyż pojęcie „unijne prawo podatkowe” czy też „prawo podatkowe UE” można rozumieć szeroko lub wąsko.

Prawo podatkowe UE sensu largo stanowi zbiór przepisów prawa unijnego (pierwotnego oraz wtórnego) dotyczących i mających wpływ na prawo podatkowe poszczególnych państw członkowskich. Do źródeł prawa podatkowego UE należą zatem nie tylko przepisy dyrektyw i rozporządzeń wpływających bezpośrednio na prawo podatkowe poszczególnych państw czy też przepisy Traktatów (TFUE i TUE) odnoszące się do opodatkowania, lecz również inne przepisy traktatowe odnoszące się do tzw. swobód europejskich, które w jakikolwiek sposób mogą wpłynąć na krajowe prawo podatkowe, przyczyniając się w ten sposób do realizacji ogólnych celów UE. Można zatem przyjąć, że są to regulacje dotyczące zarówno sfery podatków pośrednich, jak i podatków bezpośrednich oraz innych szeroko pojmowanych danin publicznych występujących w obrocie prawnym.

Prawo podatkowe UE sensu stricto stanowi natomiast zbiór przepisów prawa unijnego odnoszących się i stosowanych bezpośrednio w prawie podatkowym państw członkowskich UE. W dużym uproszczeniu można przyjąć, że są to przepisy dotyczące opodatkowania przede wszystkim podatkami pośrednimi (na obecnym poziomie legislacyjnym). Podstawy prawne polityki podatkowej UE znajdują się w TFUE. 
Przepisy TFUE stanowią narzędzie eliminacji barier w handlu o charakterze podatkowym. Zakaz podatkowej dyskryminacji towarów ma za zadanie przyczynić się do osiągnięcia rynku wewnętrznego oraz zapewnienia wolnej konkurencji poprzez równość opodatkowania towarów z różnych państw członkowskich. Zgodnie z regulacją traktatową, żadne państwo członkowskie nie nakłada bezpośrednio lub pośrednio na produkty innych państw członkowskich podatków wewnętrznych jakiegokolwiek rodzaju wyższych od tych, które nakłada bezpośrednio lub pośrednio na podobne produkty krajowe. Ponadto, żadne państwo członkowskie nie nakłada na produkty innych państw członkowskich podatków wewnętrznych, które pośrednio chronią inne produkty. W wypadku gdy produkty są wywożone na terytorium jednego z państw członkowskich, jakikolwiek zwrot podatków wewnętrznych nie może być wyższy od podatków, które zostały na nie nałożone bezpośrednio lub pośrednio. Przepisy traktatowe dotyczą jednak głównie zewnętrznych relacji podatkowych pomiędzy poszczególnymi państwami członkowskimi. Wewnętrzne regulacje podatkowe stanowią kompetencję poszczególnych państw członkowskich.

Generalizując, można postrzegać unijne prawo podatkowe jako zbiór specyficznych norm prawnych pozwalających na współistnienie na terenie UE wielu zróżnicowanych krajowych systemów podatkowych.

Stopień harmonizacji przepisów podatkowych jest zróżnicowany w zależności od rodzaju daniny publicznej pobieranej przez państwo członkowskie. Niektóre daniny podlegają całkowitej harmonizacji (np. należności celne). Wynika to z kompetencji wyłącznej UE w zakresie unii celnej. Podatki pośrednie podlegają tylko częściowej harmonizacji, a czasami dotyczy to ich tylko w niewielkim zakresie (podatki bezpośrednie). Państwa zachowują w stosunku do pewnej kategorii podatków prawie pełną swobodę regulacji (np. podatki od nieruchomości). Tak zróżnicowany poziom harmonizacji wynika między innymi ze stopnia, w jakim konkretny podatek oddziałuje na stosunki pomiędzy państwami członkowskimi.

Najwyższym poziomem konsolidacji charakteryzują się daniny publiczne, które związane są z dokonywaniem transakcji transgranicznych. Dla realizacji tej idei kwestie podatkowe znajdują się w centrum zainteresowania prawodawstwa unijnego, normowane są $\mathrm{w}$ ramach prawa pierwotnego i wtórnego Unii ${ }^{35}$. Jednolity rynek wymaga również zniesienia barier celnych, natomiast te nie powinny być w żaden sposób zastępowane w formie podatków. Unia zakłada również korzystanie z szeroko rozumianych swobód w warunkach wolnej konkurencji. Poza tym państwa członkowskie mają obowiązek współpracy administracyjnej w zakresie podatków.

${ }^{35}$ C. Kosikowski, Prawo Unii Europejskiej w systemie polskiego prawa finansowego, Białystok 2010, s. 187. 
Dlatego stworzono podstawy obowiązków państw członkowskich w zakresie harmonizacji prawa krajowego z prawem UE. Dzięki temu systemy podatkowe państw Unii Europejskiej uległy zbliżeniu, przynajmniej w kluczowych sferach, jak: podatki pośrednie i akcyza czy podatek dochodowy od przedsiębiorców ${ }^{36}$.

Celem koordynacji działań UE nie jest zastąpienie istniejących krajowych systemów podatkowych jednolitym systemem unijnym, lecz zapewnienie sprawnego współdziałania tych systemów. Podstawową wytyczną wynikającą z brzmienia traktatów jest zniesienie dyskryminacji podatkowej. Ponadto w kilku istotnych zagadnieniach niezbędne jest ustanowienie wytycznych w celu zbliżenia przepisów krajowych.

\section{Strategia Unii Europejskiej dotycząca polityki podatkowej}

Unia Europejska bardzo często w różnych dziedzinach życia społeczno-gospodarczego wprowadza specyficznie pojmowane „strategie”. Tak też jest w kontekście polityki podatkowej. Unijna strategia dotycząca polityki podatkowej została przedstawiona w komunikacie Komisji zatytułowanym Polityka podatkowa w Unii Europejskiej - priorytety na najbliższe lata ${ }^{37}$. Podkreśla się w niej, że każde państwo członkowskie ma prawo wyboru takiego systemu podatkowego, jaki uzna za najbardziej odpowiedni pod warunkiem, że przestrzega wiążących przepisów unijnych. Przy zachowaniu tych granic do głównych priorytetów polityki podatkowej UE należą między innymi: wyeliminowanie przeszkód podatkowych dla transgranicznej działalności gospodarczej, zwalczanie szkodliwej konkurencji podatkowej i promowanie ściślejszej współpracy między organami administracji podatkowej w zakresie zapewnienia kontroli oraz zwalczanie nadużyć finansowych. Większa koordynacja polityki podatkowej przyniosłaby efekty w postaci wsparcia w ramach polityki podatkowej państw członkowskich szerzej rozumianych celów politycznych UE, które zostały ostatnio określone w strategii Europa 2020 na rzecz zatrudnienia i inteligentnego, trwałego wzrostu gospodarczego sprzyjającego włączeniu społecznemu.

W komunikacie Komisji w sprawie eliminowania transgranicznych przeszkód podatkowych dla obywateli Unii ${ }^{38}$ zostały przedstawione najpoważniejsze problemy podatkowe, z którymi obywatele UE mają do czynienia w sytuacjach transgranicznych (np. dyskryminacja, podwójne opodatkowanie, trudności podczas ubiegania się o zwrot

36 Ibidem, s. 188.

${ }^{37}$ Communication from the Commission to the Council, the European Parliament and the Economic and Social Committee, Tax policy in the European Union priorities for the years ahead (2001/C 284/03) $\operatorname{COM}(2001) 260$ final.

$38 \operatorname{COM}(2010) 0769$. 
podatku i trudności z uzyskaniem informacji na temat obowiązujących za granicą przepisów podatkowych). Parlament Europejski zasadniczo poparł ogólne kierunki programów Komisji w dziedzinie podatków. W różnych sprawozdaniach podkreślał, że konkurencja podatkowa może być „skutecznym instrumentem redukcji wysokiego opodatkowania” i sprzyjać ograniczeniu obciążeń administracyjnych, a jednocześnie poprawić konkurencyjność oraz zmodernizować europejski model społeczny. Już w 2010 r. Parlament Europejski przyjął sprawozdanie w sprawie wspierania dobrych rządów w dziedzinie opodatkowania, w którym opowiedział się za odpowiedzialną polityką podatkową, przejrzystością, wymianą informacji na wszystkich szczeblach - krajowym, europejskim i światowym - oraz poparł uczciwą konkurencję podatkową.

Utrzymanie zasady jednomyślności w sprawie wszystkich decyzji podatkowych sprawia, że trudno jest osiągnąć wymagany na szczeblu UE poziom koordynacji podatkowej, w związku z czym Komisja przedstawiła wnioski, których celem jest wprowadzenie głosowania większością kwalifikowaną w odniesieniu do wybranych aspektów polityki podatkowej. Państwa członkowskie (bardzo słusznie!) nie chcą jednak przystać na te propozycje. Polityka podatkowa w dalszym ciągu leży w gestii państw członkowskich. Unia Europejska powinna z tego powodu szanować różne systemy podatkowe państw członkowskich i nadawać priorytetowe znaczenie środkom podatkowym zorientowanym na wzrost, a także promowaniu podatków konsumpcyjnych, ponieważ są lepiej niż podatki od dochodów z pracy przystosowane do stymulowania wzrostu gospodarczego i zatrudnienia w perspektywie długookresowej.

Trzy rodzaje kompetencji unijnych wskazane w traktatach (wyłączne, dzielone, wspierające) można ująć w dwie zasadnicze grupy. Zakres kompetencji wyłącznych Unii Europejskiej wyznacza bowiem zakres kompetencji niewyłącznych. Są to bowiem wszystkie pozostałe. O ile kompetencje wyłączne stanowią jedną grupę, to daje się zauważyć istotne zróżnicowanie pomiędzy kompetencjami niewyłącznymi.

Prawo podatkowe Unii Europejskiej nie wyodrębniło się z prawa unijnego w tak dużym stopniu, aby już teraz stworzyć nowy, oddzielny system unijnego prawa podatkowego. Nie jest też ponadnarodowym systemem podatkowym. Stanowi integralną część szeroko pojętego prawa unijnego oraz opiera się na jego aktach prawnych i instytucjach. Z drugiej strony unijne prawo podatkowe jest zjawiskiem zupełnie nowym, niespotykanym w dotychczasowej historii zarówno Europy, jak i świata. Cechuje je wielojęzyczność i wielokulturowość. Już ta cecha powodować może znaczne trudności w jego prawidłowej i jednolitej wykładni. Może to powodować zróżnicowaną interpretację, co nie jest zjawiskiem pożądanym w kontekście zasady pewności i jasności prawa podatkowego. Prawo podatkowe UE jako nierozerwalnie połączone i dotąd 
niewyodrębnione z systemu prawa Unii, służyło od początku realizacji jej celów. Dlatego też jego wykładnia i interpretacja przebiegać powinna zupełnie inaczej niż wykładnia krajowego prawa podatkowego poszczególnych państw członkowskich ${ }^{39}$.

System prawny Unii Europejskiej w sferze podatków stawia wymagania państwom członkowskim w przedmiocie ujednolicenia ich przepisów w kontekście wspólnego rynku wewnętrznego. Harmonizacja kwestii danin publicznych odgrywa istotną rolę w lepszej integracji gospodarczej Unii i realizacji jej podstawowych celów, do których niewątpliwie zaliczyć można stworzenie rynku wewnętrznego. Panuje selektywne podejście do harmonizacji podatków państw członkowskich Unii Europejskiej. Najwięcej uwagi w tej materii poświęca się podatkom pośrednim, ze względu na konkretny wpływ na prawidłowe funkcjonowanie rynku wewnętrznego. Natomiast opodatkowanie bezpośrednie podlega dostosowaniu jedynie w szczątkowym zakresie. Harmonizacja w tej dziedzinie następuje wówczas, gdy odmienne uregulowania poszczególnych państw członkowskich mogłyby ograniczać swobodę przepływu kapitału pomiędzy tymi krajami czy też mogłyby być dyskryminujące. Państwa członkowskie dysponują znaczną swobodą w projektowaniu swoich systemów podatków bezpośrednich, co umożliwia im realizację celów i wymogów polityki wewnętrznej. Polska, jak i inne państwa członkowskie UE, zachowała w tej materii autonomię polityki fiskalnej i prawo ustalania stawek podatków. Autonomia taka pozostała także w sferze organizacyjno-strukturalnej. To poszczególne państwa członkowskie same (w zależności od potrzeb i politycznej wizji administracji) kształtują charakter, strukturę oraz zadania administracji skarbowych. Nie oznacza to jednak, że w przyszłości taka swoboda zostanie w całości utrzymana. W Unii Europejskiej widać bowiem tendencje do centralizacji i stopniowego „zajmowania pola” poprzez coraz większy wpływ prawa unijnego i administracji unijnej na różne obszary życia społeczno-gospodarczego. W przyszłości może to dotyczyć również polityki oraz administracji podatkowej i to nie tylko w zakresie podatków pośrednich ${ }^{40}$.

\section{Bibliografia}

Andrzejewska-Czernek I., Wykładnia prawa podatkowego Unii Europejskiej, Warszawa 2013. Communication from the Commission to the Council, the European Parliament and the Economic and Social Committee, Tax policy in the European Union priorities for the years ahead (2001/C 284/03) COM(2001) 260 final.

${ }^{39}$ I. Andrzejewska-Czernek, op.cit., s. 30-31.

${ }^{40} \mathrm{~Np}$. ujednolicenie sankcji karno-skarbowych za przestępstwa/wykroczenia transgraniczne. 
Dobrowolski M., Zasada suwerenności narodu w warunkach integracji Polski z Uniq Europejska, Lublin 2014.

Ehrlich L., Prawo międzynarodowe, Warszawa 1958.

Justyńska P., Między supremacja a pierwszeństwem prawa unijnego. Jedność w różnorodności, w: Konferencja. Unia Europejska: zjednoczeni w różnorodności, Warszawa 14-15 grudnia 2010, red. C. Mik, Warszawa 2012.

Konstytucja Rzeczypospolitej Polskiej z dnia 2 kwietnia 1997 r., Dz. U. z 1997 r., nr 78, poz. 483 ze zm.

Kosikowski C., Prawo Unii Europejskiej w systemie polskiego prawa finansowego, Białystok 2010.

Kuś A., 10 lat Polski w Unii Europejskiej, „Przegląd Akademicki” 2014, nr 3.

Kuś A., Kompetencje wyłączne Unii Europejskiej w zakresie Wspólnej Polityki Handlowej i Unii Celnej, Wydawnictwo KUL, Lublin 2012.

Mik C., Europejskie prawo wspólnotowe. Zagadnienia teorii i praktyki, Warszawa 2000.

Orzeczenie ETS z 5 marca 1963 r. w sprawie Van Gend en Loos 26/62.

Relacje między prawem konstytucyjnym a prawem wspólnotowym w orzecznictwie sądów konstytucyjnych państw UE, red. K. Zaradkiewicz, Warszawa 2010.

Saganek P., Artykuł 5, w: Traktat ustanawiający Wspólnotę Europejską. Komentarz, red. A. Wróbel, t. 1 (art. 1-60), Warszawa 2008.

Saganek P., Nowe reguły dotyczące podziału kompetencji między Unię Europejską a państwa członkowskie w świetle Traktatu z Lizbony, „Przegląd Sejmowy” 2010, nr 4.

Selera P., Prawo unijne a metody unikania podwójnego opodatkowania, „Europejski Przegląd Sądowy" 2010, nr 12.

Traktat o funkcjonowaniu Unii Europejskiej, Dz. U. C. 326 z 26 października 2012 r.

Traktat z Lizbony zmieniający Traktat o Unii Europejskiej i Traktat ustanawiający Wspólnotę Europejską podpisany w Lizbonie dnia 13 grudnia 2007 r. (OJ C 306, 17.12.2007).

Wyrok TK z dnia 24 listopada 2010 r. (sygn. akt K 32/09). 